\begin{tabular}{|c|l|}
\hline Title & $\begin{array}{l}\text { Effect of the binder content on the electrochemical performance of composite cathode using Li6PS5CI precursor } \\
\text { solution in an all-solid-state lithium battery }\end{array}$ \\
\hline Author(s) & Rosero-Navarro, Nataly Carolina; Kinoshita, Taiki; Miura, A kira; Higuchi, Mikio; Tadanaga, Kiyoharu \\
\hline Citation & $\begin{array}{l}\text { Ionics, 23(6), 1619-1624 } \\
\text { https://doi.org/10.1007/311581-017-2106-x }\end{array}$ \\
\hline Issue Date & 2017-06 \\
\hline Doc URL & http://hdl.handle.net/2115/68019 \\
\hline Rights & The final publication is available at link.springer.com \\
\hline Type & article (author version) \\
\hline File Information & Ionics proofing.pdf \\
\hline
\end{tabular}

Instructions for use 


\section{Effect of the binder content on the} electrochemical performance of composite cathode using $\mathrm{Li}_{6} \mathrm{PS}_{5} \mathrm{Cl}$ precursor solution in an all-solid-state lithium battery

Nataly Carolina Rosero-Navarro, ${ }^{1}{ }^{*}$

Phone +81 011-706-6574

Email rosero@eng.hokudai.ac.jp

Taiki Kinoshita, 1

Akira Miura, ${ }^{1}$

Mikio Higuchi, 1

Kiyoharu Tadanaga, 1

1 Division of Applied Chemistry, Faculty of Engineering, Hokkaido

University, Kita 13 Nishi8, Kita-ku, Sapporo, Hokkaido, 060-8628 Japan

\section{Abstract}

All-solid-state batteries with cathode composites containing high concentration of active materials are required to achieve higher energy densities. Here, a composite cathode containing up to $89 \mathrm{wt} \%$ of high-voltage cathode active material $\left(\mathrm{LiNi}_{1 / 3} \mathrm{Mn}_{1 / 3} \mathrm{Co}_{1 / 3} \mathrm{O}_{2}\right)$ was prepared by covering this with a solutionderived solid electrolyte (argyrodite, $\mathrm{Li}_{6} \mathrm{PS}_{5} \mathrm{Cl}$ ) and the incorporation of different content binder (ethyl cellulose). All-solid-state batteries were fabricated using $80 \mathrm{Li}_{2} \mathrm{~S} \cdot 20 \mathrm{P}_{2} \mathrm{~S}_{5}(\mathrm{~mol} \%)$ glass and indium metal as a solid electrolyte and anode, respectively. The all-solid-state battery with a composite cathode containing $0.5 \mathrm{wt} \%$ of ethyl cellulose showed an initial discharge capacity of $45 \mathrm{mAhg}^{-1}$ at $25{ }^{\circ} \mathrm{C}$ and maintained $91.7 \%$ of the discharge capacity after ten cycles, around $30 \%$ higher than that obtained for the battery with the composite cathode without a binder. 


\section{Keywords}
All-solid-state battery
Binder
Sulfide solid electrolytes
Solution process

Argyrodite conductive layer

\section{Introduction}

All-solid-state lithium batteries based on sulfide solid electrolytes are a very attractive proposal to outperform limitations due to safety issues of the conventional lithium ion batteries based on organic electrolytes. The major challenges are as follows (i) to form a good ionic conduction path through the solid interface between electrode and electrolyte and (ii) to reduce the strain/stress at the electrode/electrolyte interface due to the volume change during lithiation/delithiation [ 1,2]. The composite cathodes for all-solid-state batteries based on sulfide solid electrolytes are typically prepared by mixing the active material and additives to improve both the electronic (e.g., vapor-grown carbon fiber, acetylene black) and lithium ion (e.g., solid electrolytes) conduction. The addition of the sulfide-based solid electrolytes in the composite cathode by simple mixing $[3,4]$ has been proven to be effective to improve the battery performance. This is because sulfide materials provide of good intimate contact with composite electrodes through a simple cold pressing due to its low Young's modulus [5]. In order to obtain a good enough lithium pathway to the cathode material, however, rather high concentrations of solid electrolyte (25-30 wt \%) are needed. The main drawback is to obtain homogenous and well-connected distribution of the phases though the composite cathode layer. Lower interfacial electrode/electrolyte resistances have been obtained by means of the deposition of solid electrolyte thin layer on the active materials. For example, $\mathrm{Li}_{2} \mathrm{~S}-\mathrm{P}_{2} \mathrm{~S}_{5}$ and $\mathrm{Li}_{6} \mathrm{PS}_{5} \mathrm{Cl}$ (argyrodite) solid electrolytes (SE) layers have been deposited on $\mathrm{LiCoO}_{2}$ particles by means of the pulsed laser deposition (PLD) and solution procedures, respectively [ 1,6$]$. In both cases, the formation of the continuous layer of solid electrolyte on the $\mathrm{LiCoO}_{2}$ led to a considerable reduction of the concentration of solid electrolyte into composite cathode, up to 3 [1] to $7.5 \mathrm{wt} \%$ [6]. The all-solid-state batteries using $\mathrm{LiCoO}_{2}$ with these solid electrolytes showed higher capacities $(45-85 \mathrm{mAh} / \mathrm{g})$ compared to the $\mathrm{LiCoO}_{2}$ without solid electrolyte $(20 \mathrm{mAh} / \mathrm{g})[1,6]$. The solution procedure is a simple process to produce favorable interfaces because the liquid phases can cover effectively the solid particles and after solvent removal, produces 
an adequate ionic pathway. In the preparation of $\mathrm{Li}_{6} \mathrm{PS}_{5} \mathrm{Cl}$ through the solution process, ethanol was used for the solvent [6]. Other solvents used to prepare solid electrolyte solutions are anhydrous hydrazine [7] $\left(\mathrm{Li}_{3.25} \mathrm{Ge}_{0.25} \mathrm{P}_{0.75} \mathrm{~S}_{4}\right.$, $\left.\sigma=1.82 \times 10^{-4} \mathrm{~S} / \mathrm{cm}\right)$, tetrahydrofuran $[8]\left(\beta-\mathrm{Li}_{3} \mathrm{PS}_{4}, \sigma=1.6 \times 10^{-4} \mathrm{~S} / \mathrm{cm}\right)$, acetonitrile [9] $\left(\mathrm{Li}_{7} \mathrm{P}_{2} \mathrm{~S}_{8} \mathrm{I}, \sigma=6.3 \times 10^{-4} \mathrm{~S} / \mathrm{cm}\right)$, N-methylformamide [10] $\left(\mathrm{Li}_{3} \mathrm{PS}_{4}\right.$, $\left.\sigma=2.6 \times 10^{-6} \mathrm{~S} / \mathrm{cm}\right)$, methanol [11] $\left(\mathrm{LiI}_{-}-\mathrm{Li}_{4} \mathrm{SnS}_{4}, \sigma=4.1 \times 10^{-4} \mathrm{~S} / \mathrm{cm}\right)$, and ethanol [6] $\left(\mathrm{Li}_{6} \mathrm{PS}_{5} \mathrm{Cl}, \sigma=1.4 \times 10^{-5} \mathrm{~S} / \mathrm{cm}\right)$. Solvents such as methanol or ethanol are more attractive to scalable procedures since they have low boiling points that allow the composite cathode to be obtained easily.

In addition to improve the solid interface between electrode and electrolyte, the incorporation of other agents such as binders could help the reduction of the strain/stress during charge/discharge procedures. The precursor solution of the solid electrolyte could also help the dissolution and good distribution of the binder material. The use of binders has been widely extended in the composite cathode/anode for lithium secondary batteries using liquid electrolytes since they promote the electrical contact between active materials and the current collectors [12]. Also, they provide structural robustness, and depending on their structure, they assist lithium ion conduction [12,13]. Some examples of the binders used in lithium secondary batteries using liquid electrolytes are polyethylene oxide (PEO), sodium carboxymethyl cellulose-styrene butadiene rubber (CMC-SBR), sodium alginate (SA), polyvinylpyrrolidone (PVP), carbonyl-b-cyclodextrin, gelatin, LA132 (a copolymer of acrylonitrile, acrylamide, and acrylic), and ethyl cellulose $[12,13,14]$. Among these, the carboxymethyl cellulose or the combination of CMC-SBR has proven to be effective to reduce the strain/stress of cathode materials used in lithium secondary batteries because their structure shows a higher chain flexibility to enable favorable dispersibility on the surface of active material [13].

To date, from the best of our knowledge, the use of binders in all-solid-state batteries based in sulfide electrolytes has been only slightly explored because the sulfide electrolyte can also work as a binder in the composite electrolyte. However, in high active material contents, binder should help the compensation of volume change during the charge and discharge process. Here, we report, for the first time, the effect of the binder content on the electrochemical performance of all-solidstate lithium batteries prepared with a composite cathode with a high content of active material $\left(\mathrm{LiNi}_{1 / 3} \mathrm{Mn}_{1 / 3} \mathrm{Co}_{1 / 3} \mathrm{O}_{2}, 89 \mathrm{wt} \%\right.$ ) covered with a solution-derived solid electrolyte. The precursor solution of argyrodite $\left(\mathrm{Li}_{6} \mathrm{PS}_{5} \mathrm{Cl}\right)$ solid electrolyte 
in ethanol [6] was used to disperse the ethyl cellulose binder and prepare the improved composite cathodes.

\section{Experimental}

The synthesis of the composite cathodes and the assembly of the cells were conducted in a glove box under an argon atmosphere $\left(\mathrm{H}_{2} \mathrm{O} \leq 5 \mathrm{ppm}, \mathrm{O}_{2} \leq 1 \mathrm{ppm}\right)$. The composite cathodes were prepared using $\mathrm{LiNbO}_{3}$-coated $[4,15]$ $\mathrm{LiNi}_{1 / 3} \mathrm{Mn}_{1 / 3} \mathrm{Co}_{1 / 3} \mathrm{O}_{2}$ (NMC), $\mathrm{Li}_{6} \mathrm{PS}_{5} \mathrm{Cl}$, and vapor-grown carbon fiber (VGCF, Showa Denko) as the active material, solid electrolyte, and conductive additive, respectively. The ethyl cellulose (abt. 49\% ethoxy, Wako Pure Chemicals) was used as a binder.

The powder of $\mathrm{Li}_{6} \mathrm{PS}_{5} \mathrm{Cl}$ was firstly prepared by mechanical milling using $\mathrm{Li}_{2} \mathrm{~S}$ (Mitsuwa's Purity Chemicals, 99.9\%), $\mathrm{P}_{2} \mathrm{~S}_{5}$ (Sigma Aldrich, 99\%), and $\mathrm{LiCl}$ (Sigma Aldrich, 99.9\%) as starting materials. The mechanical milling was performed using a planetary ball mill with a zirconia pot with $0.5 \mathrm{~g}$ of sample and 10 -mm-diameter zirconia balls (15 balls) at $600 \mathrm{rpm}$ for $40 \mathrm{~h}[6,16]$. The assynthetized $\mathrm{Li}_{6} \mathrm{PS}_{5} \mathrm{Cl}$ powder was then dissolved in anhydrous ethanol (Wako Pure Chemicals, 99.5\%). Further, $\mathrm{LiNbO}_{3}$-coated $\mathrm{NMC}$ and VGCF were added to the precursor solution of the $\mathrm{Li}_{6} \mathrm{PS}_{5} \mathrm{Cl}$ to prepare the composite cathode. The binder was dissolved previously in ethanol, and then, adequate concentration was added to the precursor solution of the $\mathrm{Li}_{6} \mathrm{PS}_{5} \mathrm{Cl}$ containing $\mathrm{NMC}$ and $\mathrm{VGCF}$. The composite cathodes, with and without binder, were ultrasonicated for 3 min and dried by heating at $80{ }^{\circ} \mathrm{C}$ under vacuum for $3 \mathrm{~h}$. The composite cathodes (NMC: $\mathrm{Li}_{6} \mathrm{PS}_{5} \mathrm{Cl}-$ SE:VGCG) were evaluated in weight ratio of 69:29:2, 84:14:2, 89:9:2, and 98:0:2. The effect of the binder content was evaluated using the composite cathode with a weight ratio of 89:9:2. The examined binder concentrations were $0.1,0.5$, and $1 \mathrm{wt} \%$.

The powders of $\mathrm{Li}_{6} \mathrm{PS}_{5} \mathrm{Cl}$, after mechanical milling and dissolution-reprecipitation procedures, were evaluated by Raman spectroscopy and X-ray diffraction (XRD). The measurements were carried out with a Raman spectrophotometer (XploRA Horiba) and X-ray diffractometer (MultiFlex600, Rigaku) using $\mathrm{CuK} \alpha$ radiation. The ionic conductivity of the $\mathrm{Li}_{6} \mathrm{PS}_{5} \mathrm{Cl}$ powders, obtained by mechanical milling and dissolution-reprecipitation procedure, was determined using electrochemical impedance spectroscopy (SI1260, Solartron). Impedance spectra were recorded between 1 and $1 \times 10^{6} \mathrm{~Hz}$ at room temperature. 
All-solid-state batteries were constructed using $80 \mathrm{Li}_{2} \mathrm{~S} \cdot 20 \mathrm{P}_{2} \mathrm{~S}_{5}(\mathrm{~mol} \%)$ glass and In metal (99.99\% 0.1-mm thickness) as solid electrolyte and anode, respectively. The $80 \mathrm{Li}_{2} \mathrm{~S} \cdot 20 \mathrm{P}_{2} \mathrm{~S}_{5}$ solid electrolyte was prepared by mechanical milling using $\mathrm{Li}_{2} \mathrm{~S}$ (Mitsuwa Purity Chemicals, 99.9\%) and $\mathrm{P}_{2} \mathrm{~S}_{5}$ (Sigma Aldrich, 99\%). The mechanical milling was carried out using a planetary ball mill with a zirconia pot, $1 \mathrm{~g}$ of sample and 4-mm-diameter zirconia balls (500 balls) at $510 \mathrm{rpm}$ for $10 \mathrm{~h}$. The composite cathode $(10 \mathrm{mg})$ and the solid electrolyte powder $(80 \mathrm{mg})$ were pressed under $360 \mathrm{MPa}$ in a polycarbonate tube $(\phi=10 \mathrm{~mm})$. The indium metal (40 mg) was pressed under $240 \mathrm{MPa}$ on the prepared pellet. The three-layered pellet was sandwiched between two stainless steel disks as current collectors to fabricate two electrode cells. The electrochemical performance of the cell was evaluated under a constant current density of $0.064 \mathrm{~mA} \mathrm{~cm}^{-2}$ in the voltage range from 2.0 to $3.8 \mathrm{~V}$ vs. Li-In at room temperature, using a charge discharge measuring device (Scribner Associates, 580 battery type system).

\section{Results and discussion}

Figure 1 shows XRD patterns and Raman spectra of the $\mathrm{Li}_{6} \mathrm{PS}_{5} \mathrm{Cl}$ solid electrolyte obtained by mechanical milling and dissolution-reprecipitation procedure, without and with $0.1 \mathrm{wt} \%$ of binder. The XRD pattern of the as-synthetized $\mathrm{Li}_{6} \mathrm{PS}_{5} \mathrm{Cl}$ solid electrolyte prepared by mechanical milling shows broad peak characteristic of the argyrodite crystal phase $[16,17,18]$ and additional peaks attributed to the unreacted $\mathrm{Li}_{2} \mathrm{~S}$ phase.

\section{Fig. 1}

XRD patterns (a) and Raman spectra (b) of $\mathrm{Li}_{6} \mathrm{PS}_{5} \mathrm{Cl}$ solid electrolyte obtained by (a) mechanical milling and (b) and (c) dissolution-reprecipitation procedure. Sample (c) from the precursor solution of $\mathrm{Li}_{6} \mathrm{PS}_{5} \mathrm{Cl}$ containing $0.1 \mathrm{wt} \%$ of binder 

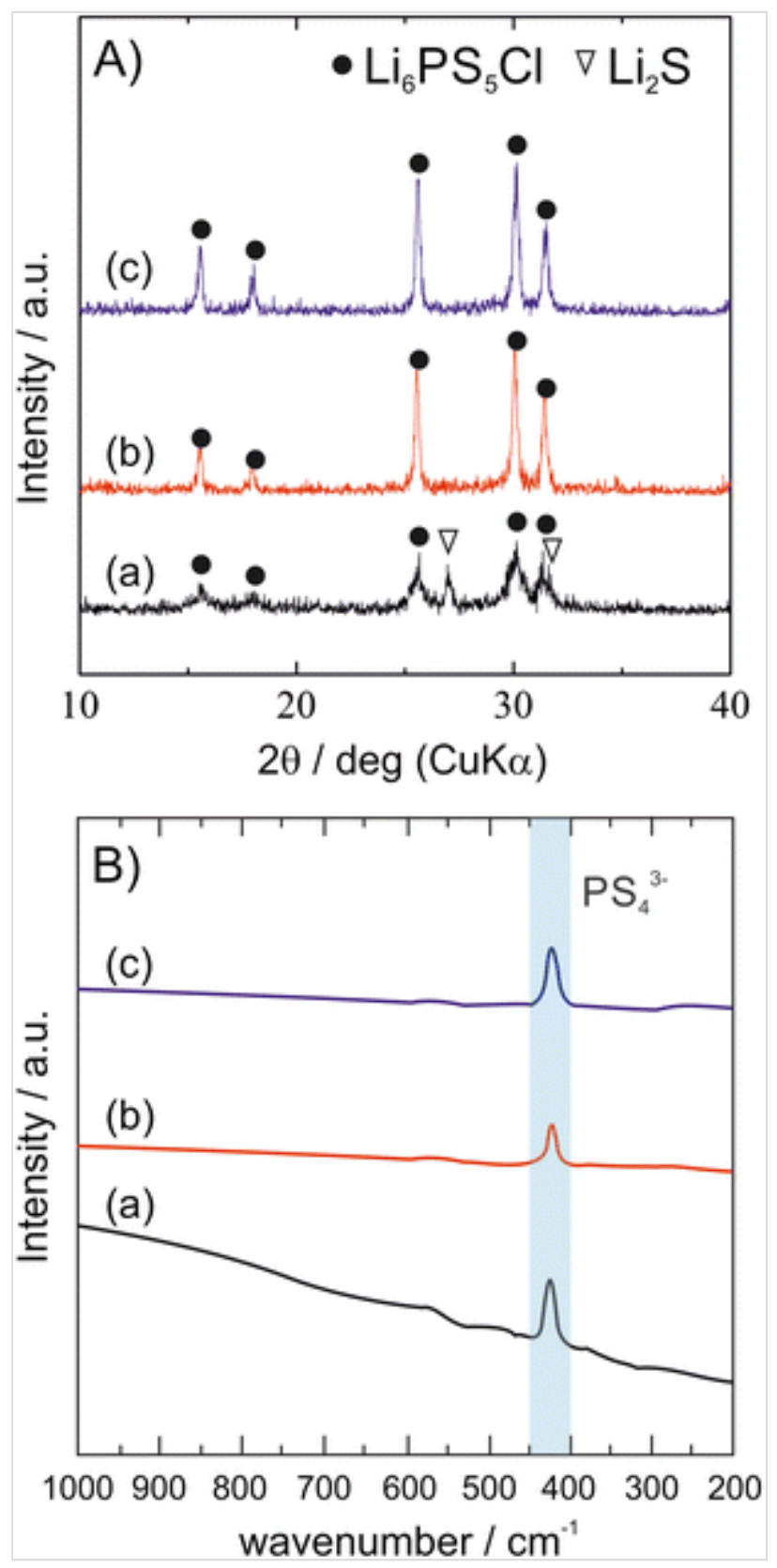

The XRD patterns of $\mathrm{Li}_{6} \mathrm{PS}_{5} \mathrm{Cl}$ crystals after dissolution-reprecipitation procedure, with and without binder, show sharper peaks than those of $\mathrm{Li}_{6} \mathrm{PS}_{5} \mathrm{Cl}$ obtained by mechanical milling, confirming a higher crystallinity after dissolutionreprecipitation procedure. Although $\mathrm{Li}_{2} \mathrm{~S}$ secondary phase was not observed on the XRD patterns of $\mathrm{Li}_{6} \mathrm{PS}_{5} \mathrm{Cl}$ crystals after dissolution-reprecipitation procedure, the possible $\mathrm{Li}_{2} \mathrm{~S}$ can be easily compensated by the addition of the carbon [19] (VGCF, $2 \mathrm{wt} \%$ ) in the cathode composite. J. Auvergniot et al. [20] have also identified the presence of $\mathrm{Li}_{2} \mathrm{~S}$ in the $\mathrm{Li}_{6} \mathrm{PS}_{5} \mathrm{Cl}$ solid electrolyte, and they have proven that the $\mathrm{Li}_{2} \mathrm{~S}$ initially present in the argyrodite disappears during charge process due to oxidation process with cathode active material. 
Raman spectra (Fig. 1 b) show a band of around $380 \mathrm{~cm}^{-1}$ associated to the $\mathrm{PS}_{4}{ }^{3-}$ group. The structure of argyrodite is formed by a network of isolated $\mathrm{PS}_{4}{ }^{3-}$ units making hexagonal cages, which are connected to each other by an interstitial site around the halide ions $[6,21,22]$. The results confirm that the process of dissolution-reprecipitation and the addition of the binder do not produce negative effects on the structure of the $\mathrm{Li}_{6} \mathrm{PS}_{5} \mathrm{Cl}$ solid electrolyte.

Figure 2 shows the $\mathrm{AC}$ impedance plots of $\mathrm{Li}_{6} \mathrm{PS}_{5} \mathrm{Cl}$ obtained by mechanical milling and dissolution-reprecipitation procedures, without and with $0.1 \mathrm{wt} \%$ of binder. The spectra consist of a well-defined semicircle at high frequency and a capacitive tail at low frequency due to the electrodes interfacial procedures. The total resistances (bulk and grain boundary resistances), used to calculate the ionic conductivity of each sample, are indicated by the arrows in the figure. The impedance spectra of $\mathrm{Li}_{6} \mathrm{PS}_{5} \mathrm{Cl}$ obtained by mechanical milling do not display the full semicircle due to the lower resistance. In this case, the resistance was estimated by the value of $Z^{\prime}$ at the intercept with the real axis obtained by linear fitting. The ionic conductivity of the $\mathrm{Li}_{6} \mathrm{PS}_{5} \mathrm{Cl}$ crystal prior to the dissolution was $5 \times 10^{-5} \mathrm{~S} \mathrm{~cm}^{-1}$. After dissolution-reprecipitation procedure, the ionic conductivity of the $\mathrm{Li}_{6} \mathrm{PS}_{5} \mathrm{Cl}$ crystal was $1.8 \times 10^{-5} \mathrm{~S} \mathrm{~cm}^{-1}$. The incorporation of the binder produced a slight improvement on the conductivity, achieving $2.5 \times 10^{-5} \mathrm{~S} \mathrm{~cm}^{-1}$. The lithium conductivity of the $\mathrm{Li}_{6} \mathrm{PS}_{5} \mathrm{Cl}$ crystal as-synthetized obtained in this work is lower when compared with the reported literature $\left(1 \times 10^{-3} \mathrm{~S} \mathrm{~cm}^{-1}\right)$ $[6,21]$. The presence of $\mathrm{Li}_{2} \mathrm{~S}$ phase, detected by XRD, could be responsible for the low ionic conductivity of the material obtained after ball milling procedures. After the dissolution-reprecipitation procedure, the crystallinity of the sample was improved with a small loss of the ionic conductivity, maintaining the same order of magnitude of the $\mathrm{Li}_{6} \mathrm{PS}_{5} \mathrm{Cl}$ crystal as-synthetized. Similar observations were reported by Yubuchi et al. [6], who assumes that the loss of the conductivity after dissolution-reprecipitation procedures is because of the increase of the grain boundary resistance. The reason for the high grain boundary resistance is believed to be because of high crystallinity of the precipitated $\mathrm{Li}_{6} \mathrm{PS}_{5} \mathrm{Cl}$ powders that results in a bad densification by pelletizing $[6,23]$. On the other hand, the improved conductivity obtained with the presence of the ethyl cellulose can be related to the better densification of the material. It is well known that when the binder is in contact with the particle surfaces of the active material and carbon materials, the polymer improves the mechanical strength of the composite cathode by the formation of a continuous network layer of the polymer on the surface of the particles of active material [24, 25]. Addition of a larger binder amount, however, 
could decrease the ionic conductivity of the solid electrolyte due to its low conductivity.

\section{Fig. 2}

Nyquist plot of $\mathrm{Li}_{6} \mathrm{PS}_{5} \mathrm{Cl}$ solid electrolyte obtained by (a) mechanical milling and (b) and (c) dissolution-reprecipitation procedure. Sample (c) from the precursor solution of $\mathrm{Li}_{6} \mathrm{PS}_{5} \mathrm{Cl}$ containing $0.1 \mathrm{wt} \%$ of binder

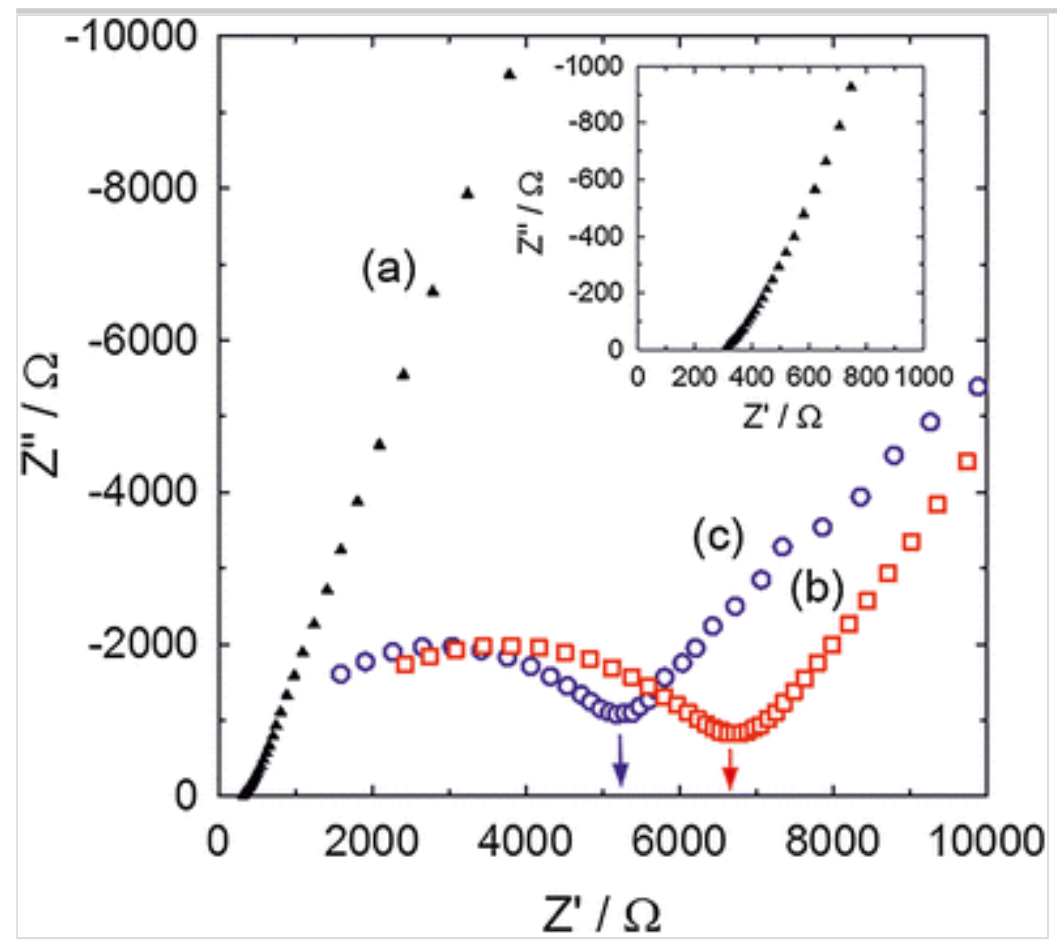

Figure 3 shows initial discharge curves of all-solid-state cells using different content of the $\mathrm{Li}_{6} \mathrm{PS}_{5} \mathrm{Cl}$ solid electrolyte (SE) derived from solution in the composite cathode (NMC: $\left.\mathrm{Li}_{6} \mathrm{PS}_{5} \mathrm{Cl}-\mathrm{SE}: \mathrm{VGCF}\right)$ at a current density of $0.064 \mathrm{~mA} \mathrm{~cm}^{-2}$. The electronic conduction was guaranteed by the addition of $2 \mathrm{wt} \%$ of VGCF. The capacity was normalized by the weight of the NMC active material.

Fig. 3

Initial discharge curves of the all-solid-state cell using $\mathrm{In} / 80 \mathrm{Li}_{2} \mathrm{~S} \cdot 20 \mathrm{P}_{2} \mathrm{~S}_{5}$ glass/cathode composite using $\mathrm{NCM}$ particles coated with the $\mathrm{Li}_{6} \mathrm{PS}_{5} \mathrm{Cl}$ solid electrolyte. The legends in the figure correspond to the weight ratio of the cathode composite (NMC: $\mathrm{Li}_{6} \mathrm{PS}_{5} \mathrm{Cl}-\mathrm{SE}: \mathrm{VGCF}$ ) 


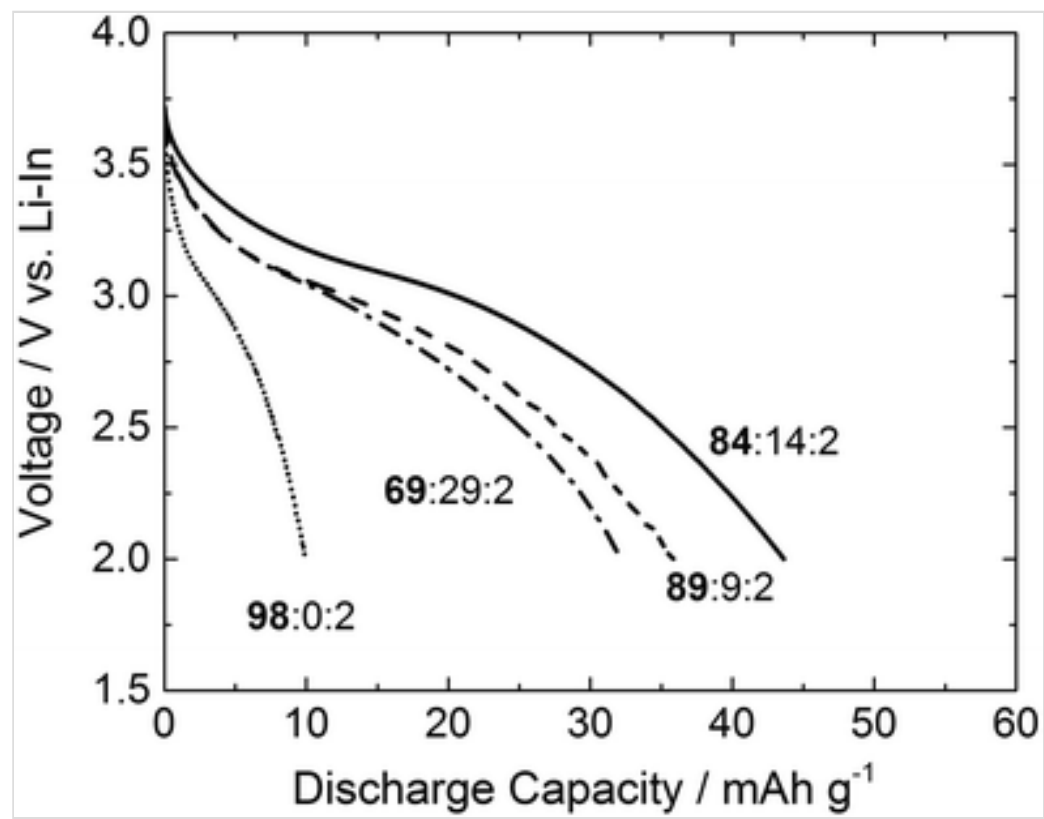

The all-solid-state battery using $\mathrm{NMC}$ without $\mathrm{Li}_{6} \mathrm{PS}_{5} \mathrm{Cl}$ solid electrolyte showed a small capacity of around $9 \mathrm{mAh} \mathrm{g}^{-1}$. The all-solid-state battery using NMC with solution-derived $\mathrm{Li}_{6} \mathrm{PS}_{5} \mathrm{Cl}$ solid electrolyte led to better battery performances. The capacity of the battery increases is as high as the content of the solid electrolyte in the composite cathode. The composite cathode with a weight ratio of 84:14:2 displayed higher reversible capacity of $44 \mathrm{mAh} \mathrm{g}^{-1}$. The tendency of the battery capacities indicates that the solid electrolyte, which formed in the composite cathode, facilitated the formation of a lithium ion conducting path in the cathode composite $[1,6]$. Further, the excess of solid electrolyte, the composite cathode with a weight ratio of 69:29:2, yielded the drop of the capacity of the battery achieving an initial discharge capacity of $33 \mathrm{mAh} \mathrm{g}^{-1}$. The excess of $\mathrm{Li}_{6} \mathrm{PS}_{5} \mathrm{Cl}$ solid electrolyte could produce insufficient electron conduction path affecting the battery performance.

The effect of the binder content was evaluated using the composite cathode with a weight ratio of $89: 9: 2$, which is the composition with a rather high content of active material. The effect of the binder should be more notable at this composition, since at high content of active material, a binder should serve to mitigate the volume change during charge and discharge in the composite cathode. Figure 4 shows electrochemical performance of the all-solid-state batteries produced by the addition of different amount of the binder at a current density of $0.064 \mathrm{~mA} \mathrm{~cm}^{-2}$. Initial discharge capacity of the batteries with different content of binder (Fig. 4 a) was slightly smaller than that of the battery without binder content $\left(36 \mathrm{mAh} \mathrm{g}^{-1}\right)$. The initial discharge capacity decreases with the increase of the binder content. The $1 \mathrm{wt} \%$ of binder displays the smaller initial discharge capacity around $31 \mathrm{mAh} \mathrm{g}^{-1}$. 
Despite this, the cycling performance of the batteries with the binder content showing a different tendency (Fig. 4 b). After ten cycles, the battery without binder showed a relatively low capacity retention rate of $60 \%$. Conversely, the capacity retention rate was improved by the addition of small amounts of the binder. After ten cycles, the capacity retention rates of the batteries with 0.1 and $0.5 \mathrm{wt} \%$ of binder were 83.7 and $91.7 \%$, respectively. The increase of the binder content to $1.0 \mathrm{wt} \%$ produced a decrease in the capacity retention rate of $72.4 \%$. The study of the composite cathode composition in lithium secondary batteries using liquid electrolyte has revealed that the higher binder contents can lead to the encapsulation of individual particles of the active material producing a lithium-ion blocking effect $[24,25]$. Thus, higher binder contents than $1 \mathrm{wt} \%$ led to the loss of capacity due to the insufficient electronic conductivity in the composite cathode. The improved performance of the battery using small content of binder material can be interpreted by a favorable dispersibility of each component of the cathode composite and further, by the compensation of volume change during the charge and discharge process. The use of the binder can improve the cyclability of the composite cathode with high content of active material needed to produce high energy density.

\section{Fig. 4}

Initial discharge curves (a) and cycle performance (b) of $\mathrm{In} / 80 \mathrm{Li}_{2} \mathrm{~S} \cdot 20 \mathrm{P}_{2} \mathrm{~S}_{5}$ glass/cathode composite using $\mathrm{NCM}$ particles coated with the $\mathrm{Li}_{6} \mathrm{PS}_{5} \mathrm{Cl}$ solid electrolyte and different content of binder. The cathode composite $\left(\mathrm{NMC}: \mathrm{Li}_{6} \mathrm{PS}_{5} \mathrm{Cl}-\right.$ SE:VGCF) corresponds to a weight ratio of 89:9:2 

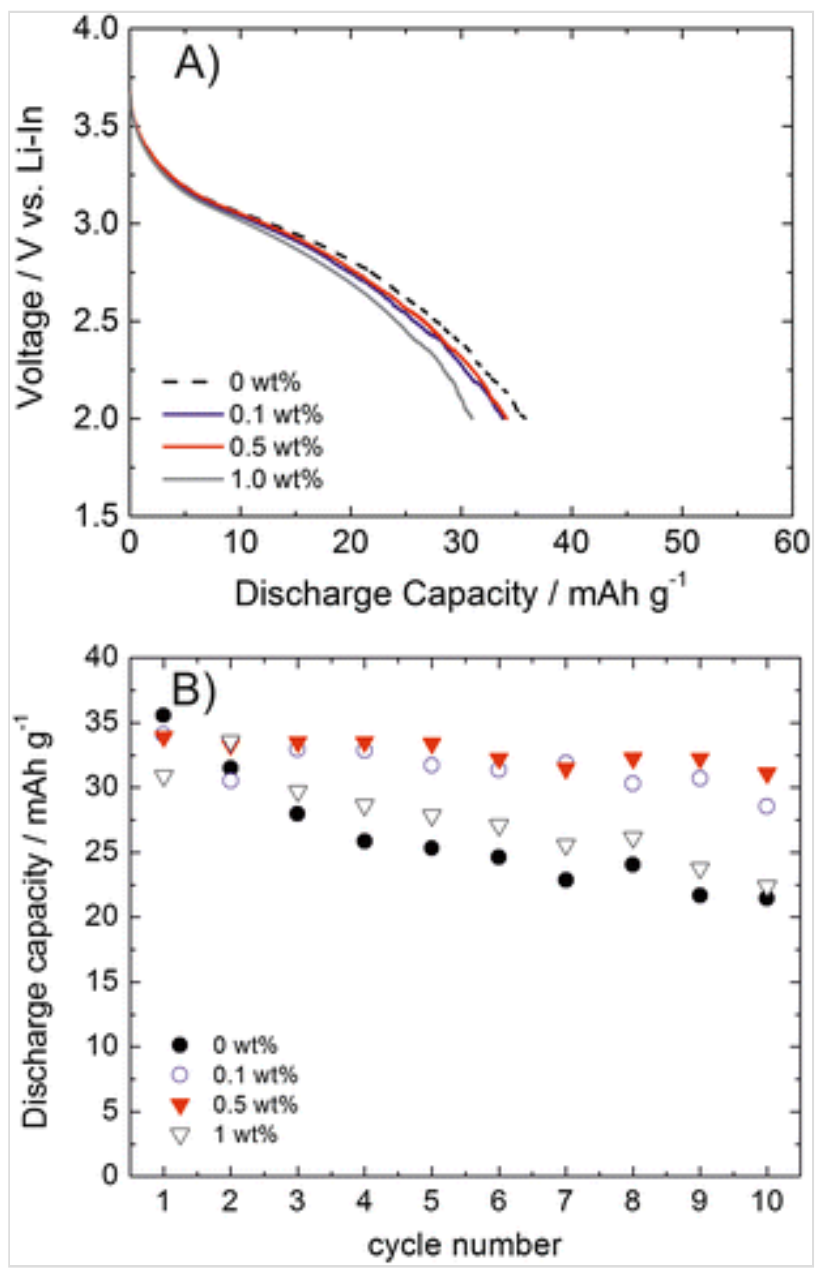

The results show that the use of solid electrolyte precursor solution and the incorporation of the binder play an important role in the battery performance of allsolid-state batteries. Further cathode composite composition with high active material content could be optimized by the selection of solvents compatible with solid electrolytes and binder materials.

\section{Conclusions}

The solution procedure is a promising method to produce efficient interfaces with an adequate lithium ion pathway between solid electrolyte and electrode-active material for all-solid-state batteries. The procedure allowed the incorporation of ethyl cellulose used as a binder to enhance the electrochemical performance of the cathode composite. The ethanol used as a solvent of the $\mathrm{Li}_{6} \mathrm{PS}_{5} \mathrm{Cl}$ solid electrolyte and the ethyl cellulose binder do not cause structural changes of the solid electrolyte confirmed by XRD and Raman studies. The use of ethyl cellulose as a binder was effective to improve the cycle life of the all-solid-state battery prepared with a composite cathode with a high content of active material up to $89 \mathrm{wt} \%$. The higher capacity retention rate was obtained by the addition of small amount of 
binder, $0.5 \mathrm{wt} \%$ of ethyl cellulose producing a capacity retention rate of $91.7 \%$ after ten cycles.

\section{Acknowledgments}

The present work was supported by the Japan Science and Technology Agency (JST), Advanced Low Carbon Technology Research and Development Program (ALCA), and Specially Promoted Research for Innovative Next Generation Batteries (SPRING) project.

\section{References}

1. Sakuda A, Hayashi A, Ohtomo T, Hama S, Tatsumisago M (2011) All-solidstate lithium secondary batteries using $\mathrm{LiCoO}_{2}$ particles with pulsed laser deposition coatings of $\mathrm{Li}_{2} \mathrm{~S}-\mathrm{P}_{2} \mathrm{~S}_{5}$ solid electrolytes. J Power Sources 196(16):6735-6741. doi: 10.1016/j.jpowsour.2010.10.103

2. Han F, Yue J, Fan X, Gao T, Luo C, Ma Z, Suo L, Wang C (2016) Highperformance all-solid-state lithium-sulfur battery enabled by a mixedconductive $\mathrm{Li}_{2} \mathrm{~S}$ nanocomposite. Nano Lett 16(7):4521-4527. doi: 10.1021/acs.nanolett.6b01754

3. Mizuno F, Hayashi A, Tadanaga K, Tatsumisago M (2005) Design of composite positive electrode in all-solid-state secondary batteries with $\mathrm{Li}_{2} \mathrm{~S}$ $\mathrm{P}_{2} \mathrm{~S}_{5}$ glass-ceramic electrolytes. J Power Sources 146(1-2):711-714. doi: 10.1016/j.jpowsour.2005.03.161

4. Sakuda A, Takeuchi T, Kobayashi H (2016) Electrode morphology in allsolid-state lithium secondary batteries consisting of $\mathrm{LiNi}_{1 / 3} \mathrm{Co}_{1 / 3} \mathrm{Mn}_{1 / 3} \mathrm{O}_{2}$ and $\mathrm{Li}_{2} \mathrm{~S}-\mathrm{P}_{2} \mathrm{~S}_{5}$ solid electrolytes. Solid State Ionics 285:112-117. doi: 10.1016/j.ssi.2015.09.010

5. Sakuda A, Hayashi A, Takigawa Y, Higashi K, Tatsumisago M (2013) Evaluation of elastic modulus of $\mathrm{Li}_{2} \mathrm{~S}_{-} \mathrm{P}_{2} \mathrm{~S}_{5}$ glassy solid electrolyte by ultrasonic sound velocity measurement and compression test. J Ceram Soc Jpn 121(1419):946-949. doi: 10.2109/jcersj2.121.957

6. Yubuchi S, Teragawa S, Aso K, Tadanaga K, Hayashi A, Tatsumisago M (2015) Preparation of high lithium-ion conducting $\mathrm{Li}_{6} \mathrm{PS}_{5} \mathrm{Cl}$ solid electrolyte 
from ethanol solution for all-solid-state lithium batteries. J Power Sources 293:941-945. doi: 10.1016/j.jpowsour.2015.05.093

7. Wang YM, Liu ZQ, Zhu XL, Tang YF, Huang FQ (2013) Highly lithium-ion conductive thio-LISICON thin film processed by low-temperature solution method. J Power Sources 224:225-229. doi: 10.1016/j.jpowsour.2012.09.097

8. Liu ZC, Fu WJ, Payzant EA, Yu X, Wu ZL, Dudney NJ, Kiggans J, Hong KL, Rondinone AJ, Liang CD (2013) Anomalous high ionic conductivity of nanoporous beta-Li $\mathrm{PS}_{4}$. J Am Chem Soc 135(3):975-978. doi: $10.1021 /$ ja3 110895

9. Rangasamy E, Liu ZC, Gobet M, Pilar K, Sahu G, Zhou W, Wu H, Greenbaum S, Liang CD (2015) An iodide-based $\mathrm{Li}_{7} \mathrm{P}_{2} \mathrm{~S}_{8} \mathrm{I}$ superionic conductor. J Am Chem Soc 137(4):1384-1387. doi: 10.1021/ja508723m

10. Teragawa S, Aso K, Tadanaga K, Hayashi A, Tatsumisago M (2014) Preparation of $\mathrm{Li}_{2} \mathrm{~S}-\mathrm{P}_{2} \mathrm{~S}_{5}$ solid electrolyte from $\mathrm{N}$-methylformamide solution and application for all-solid-state lithium battery. J Power Sources 248:939-942. doi: 10.1016/j.jpowsour.2013.09.117

11. Park KH, Oh DY, Choi YE, Nam YJ, Han LL, Kim JY, Xin HL, Lin F, Oh SM, Jung YS (2016) Solution-processable glass $\mathrm{LiI}_{-} \mathrm{Li}_{4} \mathrm{SnS}_{4}$ superionic conductors for all-solid-state Li-ion batteries. Adv Mater (Weinheim, Ger) 28(9):1874-1883. doi: 10.1002/adma.201505008

12. Chou SL, Pan Y, Wang JZ, Liu HK, Dou SX (2014) Small things make a big difference: binder effects on the performance of $\mathrm{Li}$ and Na batteries. Phys Chem Chem Phys 16(38):20347-20359. doi: 10.1039/C4CP02475C

13. Hong X, Jin J, Wen Z, Zhang S, Wang Q, Shen C, Rui K (2016) On the dispersion of lithium-sulfur battery cathode materials effected by electrostatic and stereo-chemical factors of binders. J Power Sources 324:455-461. doi: 10.1016/j.jpowsour.2016.04.114

14. Buqa H, Holzapfel M, Krumeich F, Veit C, Novák P (2006) Study of styrene butadiene rubber and sodium methyl cellulose as binder for negative electrodes in lithium-ion batteries. J Power Sources 161(1):617-622. doi:

10.1016/j.jpowsour.2006.03.073 
15. Ohta N, Takada K, Sakaguchi I, Zhang LQ, Ma RZ, Fukuda K, Osada M, Sasaki T (2007) $\mathrm{LiNbO}_{3}$-coated $\mathrm{LiCoO}_{2}$ as cathode material for all solid-state lithium secondary batteries. Electrochem Commun 9(7):1486-1490. doi: 10.1016/j.elecom.2007.02.008

16. Boulineau S, Courty M, Tarascon J-M, Viallet V (2012) Mechanochemical synthesis of Li-argyrodite $\mathrm{Li}_{6} \mathrm{PS}_{5} \mathrm{X}(\mathrm{X}=\mathrm{Cl}, \mathrm{Br}, \mathrm{I})$ as sulfur-based solid electrolytes for all solid state batteries application. Solid State Ionics 221:1-5. doi: 10.1016/j.ssi.2012.06.008

17. de Klerk NJJ, Rosłoń I, Wagemaker M (2016) Diffusion mechanism of Li argyrodite solid electrolytes for Li-ion batteries and prediction of optimized halogen doping: the effect of Li vacancies, halogens, and halogen disorder. Chem Mater 28(21):7955-7963. doi: 10.1021/acs.chemmater.6b03630

18. Yu C, van Eijck L, Ganapathy S, Wagemaker M (2016) Synthesis, structure and electrochemical performance of the argyrodite $\mathrm{Li}_{6} \mathrm{PS}_{5} \mathrm{Cl}$ solid electrolyte for Li-ion solid state batteries. Electrochim Acta 215:93-99. doi:

10.1016/j.electacta.2016.08.081

19. Lin Z, Liu Z, Dudney NJ, Liang C (2013) Lithium superionic sulfide cathode for all-solid lithium-sulfur batteries. ACS Nano 7(3):2829-2833. doi: $10.1021 / \mathrm{nn} 400391 \mathrm{~h}$

20. Auvergniot J, Cassel A, Foix D, Viallet V, Seznec V, Dedryvère R (2017) Redox activity of argyrodite $\mathrm{Li}_{6} \mathrm{PS}_{5} \mathrm{Cl}$ electrolyte in all-solid-state Li-ion battery: an XPS study. Solid State Ionics 300:78-85. doi:

10.1016/j.ssi.2016.11.029

21. Bachman JC, Muy S, Grimaud A, Chang HH, Pour N, Lux SF, Paschos O, Maglia F, Lupart S, Lamp P, Giordano L, Shao-Horn Y (2016) Inorganic solidstate electrolytes for lithium batteries: mechanisms and properties governing ion conduction. Chem Rev 116(1):140-162. doi: 10.1021/acs.chemrev.5b00563

22. Deiseroth HJ, Kong ST, Eckert H, Vannahme J, Reiner C, Zaiß T, Schlosser $\mathrm{M}$ (2008) $\mathrm{Li}_{6} \mathrm{PS}_{5} \mathrm{X}$ : a class of crystalline Li-rich solids with an unusually high $\mathrm{Li}^{+}$mobility. Angew Chem Int Ed 47(4):755-758. doi: 10.1002/anie.200703900 
23. Ito S, Nakakita M, Aihara Y, Uehara T, Machida N (2014) A synthesis of crystalline $\mathrm{Li}_{7} \mathrm{P}_{3} \mathrm{~S}_{11}$ solid electrolyte from 1,2-dimethoxyethane solvent. J Power Sources 271:342-345. doi: 10.1016/j.jpowsour.2014.08.024

24. Liu G, Zheng H, Kim S, Deng Y, Minor AM, Song X, Battaglia VS (2008) Effects of various conductive additive and polymeric binder contents on the performance of a Lithium-ion composite cathode. J Electrochem Soc 155(12):A887-A892. doi: 10.1149/1.2976031

25. Ludwig B, Zheng Z, Shou W, Wang Y, Pan H (2016) Solvent-free manufacturing of electrodes for lithium-ion batteries. Sci Rep 6:23150. doi: 10.1038/srep23150 http://www.nature.com/articles/srep23150\#supplementaryinformation 